\title{
REDEFINITION OF LUXURY FASHION BRANDING THROUGH SUSTAINABILITY RENAISSANCE: RE(F)USE CASE
}

\author{
Yrd. Doç. Dr. Hande BİLSEL ${ }^{1}$
}

\begin{abstract}
The luxury fashion industry is a global multi-billion dollar industry including a wide array of brands with massive halo effect, brand heritage and high consumer relevance such as Fendi, Prada, Louis Vuitton, Gucci and Hermes which are also among the most valuable and influential brands in the world. The established traditional methods of luxury marketing mostly focused on product innovation and exclusive brand advertising practices. With a perspective to built up a synergy between its historical heritage and the requirements of (post)modern business, the global luxury branding industry is at present facing an important challenge in consumer behavior and also going through several managerial shifts such as use of business concepts like brand equity, to e-business; and the evolution of the concepts of sustainability, recycling, provenance and fair trade applications on luxury brands. Expansion of the luxury consumer market toward a broader mass market; competition from accessible fashion brands; the redefinition of the luxury concept of the consumer society; the emergent luxury markets like China, Russia and India; and the increase and fluctuations in the world's affluent markets and finally changing attitudes and consumption patterns in luxury pose a challenge for luxury fashion brand management. This study exemplifies this shift through an accessible luxury brand discovered on a business trip made to Rome in April 2016 by the author to study established Italian luxury brands. The new Renaissance in luxury branding idea dawned on the author through a brand named RE(f)USE founded by one of the daughters of Anna Fendi, Ilaria Venturini Fendi, the Italian luxury brand artisan. RE(f)USE is a luxury brand concept in accessories based upon the three R's: Reduce, reuse and recycle. The three R's have been making their way into the fashion world with new force in recent years. The story of this new off-Roman iconoclastic Italian brand as a strong and valid example that uses recycled and upcycled materials to keep waste to a minimum while creating beautifully unique luxury products the consumers find extremely inspiring and relevant will be depicted in the study. The evolution and redefinition of luxury idea from high-fashion looks to eco-conscious downshifting with upcycled stuff, made from recycled materials will be pinpointed. As a result in response to affluenza, we also see a new luxury consumer, the post-luxury consumer, willing to participate in the voluntary simplicity movement as socially conscious affluent people expressing a variety of concerns about environment, overconsumption, abuse of developing nations and extensive advertising and this deserves further analysis.
\end{abstract}

Keywords: Luxury fashion branding, recycling, upcycling, sustainable fashion, luxury consumption, consumer society

1 Bahçeşehir Üniversitesi, Reklamcllk; hande.bilselengin@comm.bau.edu.tr 


\section{INTRODUCTION: LUXURY FASHION AS INCARNATION OF MATERIALISM}

Our 'badge' possessions play a key role in our lives and our desire to stockpile them molds our value systems. Materialism refers to the importance people attach to worldly possessions (Schultz Kleine and Menzel Baker, 2004). Materialistic values generally accentuate the well-being and social status level of the individual versus the group. Materialist fashionistas are more likely to value possessions for their status and appearance related meanings, while those who do not emphasize this value tend to appreciate products that connect them to other people or that provide them with pleasure and compassion when they use them (Richins, 1994, s. 526). As a result, high materialists usually prefer expensive luxury products that they conspicuously and publicly consume. A study comparing specific items that low versus high materialists value found that people who were non-materialists cherished items with personal significance, such as a mother's wedding dress, picture albums, a rocking chair from childhood or a garden. In contrast, high materialists preferred prestige luxury branded goods such as expensive jewelry, china or a vacation home (1994, s. 529).

Materialistic people appear to attach more of their self-identity to fashionable luxury products. Even one study found that when people who high on this value fear the prospect of dying, they form even stronger connections to brands (Rindfleisch, Burroughs and Wong, 2009, s. 10). Yet another study points out that materialists tend to value a product before they buy it since they believe it will make them happy but their enamorment of it wears off in the post-purchase phase when they find out this did not happen (Richins, 2013, s. 12-13).

Even so, consumers' demand and appetite for luxury goods and fashion continue to grow especially in developing markets where luxury goods loom large. Major industry analysts estimate dramatic growth in sales of luxury products in Europe and the United States, but with huge growth in China as well as substantial expansion in emerging markets such as Brazil, Indonesia, Azerbaijan, Kazakhstan, Malaysia, Mexico, South Africa, Vietnam and Turkey. Asian consumers, for instance, account for more than 50 percent of global luxury sales ${ }^{2}$.

Nonetheless, consumers' considerations on the importance of accumulating products as well as which items are important, clearly is changing. For instance, in the United States hot political debates taking place around the issue of ' 1 percenters' at the top of the pyramid whose incomes rise while the rest of the population still play the role of strivers to keep the system going. A case study conducted on the growth of the upscale grocery store like Whole Foods indicates that this company in its own way sells luxury products yet with a different twist (Lee, A. and Linowes, R. 2009, s. 6-14). The case points out that instead of distant, impersonal retail chains, Whole Foods provides a hip, eclectic kind of feel like a Woodstock spirit revival with no credit limit. In the words of one advertising executive "Funky music blares, dreadlocked associates staff checkout aisles and the shoppers are a mix of artsy-looking moms, retirees in pricey but well-cushioned running shoes, and a constant stream of suits taking a quick break from corporate America while awaiting a 15 dollar turkey sub and some curried sweet potato couscous" (Solomon, M. R., 2017). Hence evidently, materialists value and are even preoccupied by the fundamental qualities of what they purchase whether it is a Swarovsky or organic apples.

2 Luxury goods market predicted to grow six to seven percent in 2012, defying global turmoil and spreading to new markets according to Spring update of Bain\&Company's Luxury Goods Worldwide Market Study, Bain \& Company, May 15, 2012,

http://www.bain.com/about/press/press-releases/luxury-goods-market-predicted-to-grow-six-to-seven-percent-in-2012.aspx. 


\section{Targeting The Top Of The Pyramid: The Luxury and Post-Luxury Consumer}

Many marketers naturally try to target high-income, affluent markets since these consumers undoubtedly have the means and resources to spend on expensive items with higher profit margins on the corporate side. Yet, it would be a mistake to directly place everyone with high income into the same market segment as social class involves factors other than the absolute income such as life style, cultural and educational background and several other factors including where the money has been gained from, how it has been gained and how long it has been owned and so forth. These altogether have impact affluent consumers' interests and spending power. Although there are clichés depicting rich people as party animals and insatiable consumers, one study found that the a 57-year old, self-employed typical millionaire makes an average household income of 131.000 US dollars, has been married to the same wife for most of his adult life, has children, has never spent more than 399 US dollars on a suit or more than 140 US dollars for a pair of shoes, and drives Ford Explorer. Strangely enough many rich people do not consider themselves as to be rich. The research indicates that these people indulge themselves in luxury goods while they spend their money on their habitual shopping (Reese, S., 1997, s. 46).

SRI Consulting Business Intelligence segments consumers into three groups based on their attitudes towards luxury:

1. Luxury is functional - These consumers use their resources to make purchases that will last and have enduring value. They conduct extensive pre-purchase research and make rational decisions rather than emotional or impulsive buys.

2. Luxury is a reward. These consumers tend to be younger than the first group but older than the third group - They use luxury goods to show, "I have made it." The desire to be successful and to demonstrate their success to others motivates these consumers to purchase conspicuous luxury items such as high-end automobiles and homes in exclusive communities.

3. Luxury is indulgence - This group is the smallest of the three and tends to include younger consumers and slightly more males than other two groups. To these consumers, the purpose of owning luxury is to be extremely lavish and self-indulgent. This group is willing to pay a premium for goods that express their individuality and make others take notice. They have a more emotional approach to luxury spending and are more likely than other two groups to make impulse purchases (Gardyn, R., 2002, s. 34). 


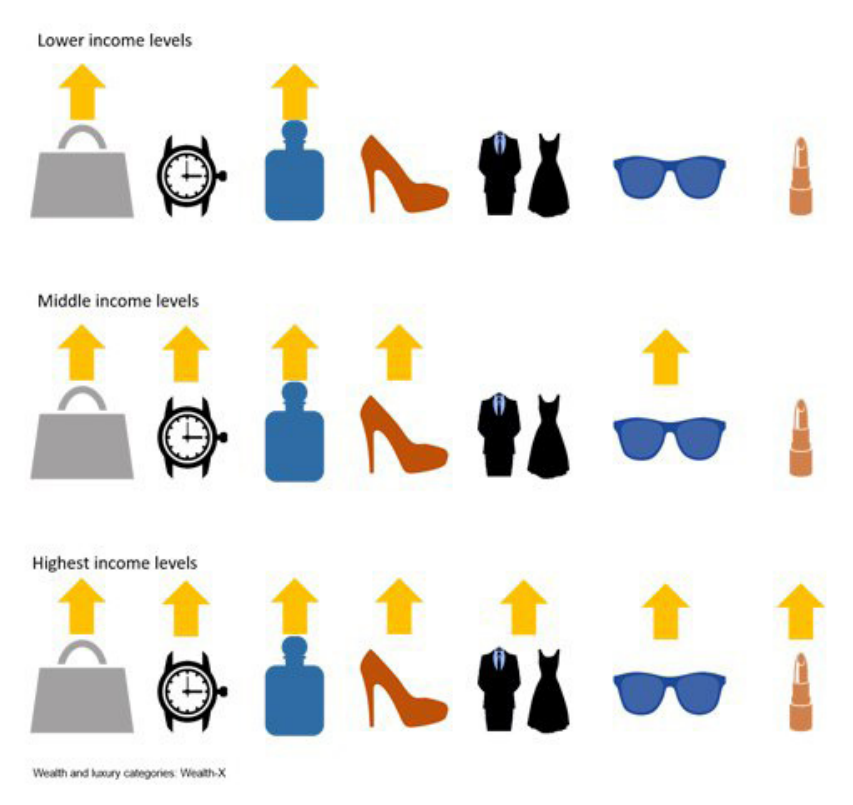

Figure: 1 Luxury and the income-upgrade phenomenon

(Chesterfield, W., 2017).

Luxury's connection to affluence and price relates most closely to income and wealth dynamics. The original 'luxury price' concept relates to the income-upgrade phenomenon; namely, whenever income and wealth increases for a particular consumer, likelihood to spend on luxury in more categories increases. Below are examples of how this manifests across the different luxury categories for different income groups of luxury consumers (L-R: Handbags/leather goods; watches; fragrance; footwear; apparel; accessories; makeup and skincare).

However, today, individuals in higher income categories no longer feel the urge to consistently upgrade into luxury as income and wealth rises. Here we come across a new concept known as 'postluxury' coined by Wealth-X's Winston Chesterfield: "Luxury is in a state of flux; whilst there are many opportunities for the industry, there are also many threats to growth. In their Global Powers of Luxury Goods study, professional services firm Deloitte highlighted four 'horsemen of the luxury apocalypse'; reputational risk, regulation and stakeholders, external events and inertia. Whilst valid and certainly points for consideration, these issues reflect the underlying problem with the luxury industry - much in the same way that an ostrich thrusts its head in the ground, luxury tends to relate only to itself. One thing that the report does not address has been an elephant in the room for the last decade - how luxury relates not just to itself but also to non-luxury. Luxury organizations can no longer ignore that the age of high-low consumption is actually a long term threat to luxury" (Chesterfield, W., 2017).

The post-luxury concept actually relates to the decline of the income-upgrade phenomenon. The post-luxury consumer no longer needs to upgrade as they progress through income categories, he or she may perform skewed patterns of shopping behavior and even might select categories that remain non-luxury. There is evidently a trend away from the income-upgrade phenomenon associated with the luxury market. Some of the most important examples are the ready to wear and soft accessories 
categories, where design has been democratized and has smashed the perception that good design always costs huge amounts of money.

The post-luxury consumers in higher income categories no longer feel the need to consistently upgrade into luxury as income and wealth rises. Luxury goods are basically sold on promises of design improvement, heritage and brand-myth over mass-produced goods which are also supported by the process through which they are produced and the value of materials used. Luxury brands now need more than just design credentials to sell in key categories, as style has begun its domination of fashion trends. Post-luxury consumers are wearing a variety of styles inspired by different eras; they are willing to replace one trend with another quickly because the cost of doing so is low and that is the post-modern spirit as well.

Moreover, social media, particularly Instagram, has increased exposure to brand new and micro business luxury brands due to the low cost-high-impact of creating brand awareness through such mediums. As a consequence, post- luxury brands investing on recent concepts such as provenance and sustainability are more careful in how they communicate their genuine attitude and story.

\section{The Changing Consumer Ideals: The Rise Of The Concepts Of Provenance, Social}

\section{Responsibility and Sustainability}

One important dimension in consumer behavior today is provenance; namely the strategy established upon the narrative behind a product, its authenticity and provenance are key drivers especially in luxury textile brands, with the perception of quality of utmost importance. Long-standing companies have interwoven provenances with their spiritual birthplaces, people and environment which can be leveraged in product introductions and branding (Collins, M. and Weiss M., 2015). New consumers are willing to pay for a product when they know precisely where it comes from and how it has been manufactured. They also want to feel assured that a real human factor has genuinely selected the items from which they choose. This process of curation which is used to refer to a savvy professional who carefully picks and chooses pieces to exhibit in a museum setting now applies to a range of consumer products such as clothing, accessories, food and travel.

Where the item was made, by whom and in what conditions now might greatly matter for the new post-luxury consumer. During the decades of rampant globalization, such questions were rarely asked yet today, ensuring more transparent supply chains and production cycles is becoming increasingly important worldwide. This shift in responsible consumption goes hand-in-hand with a heightened consciousness toward environmental sustainability, which is no longer an optional for luxury brands. Young fashion luxury labels such as Everlane and Outdoor Voices have built immense appeal with Millennials by building a foundation out of sustainability. They have set the tone by which future brands will need to live by if they want to stand the test of time and avoid growing criticism of unethical production within the fashion industry.

The socially-aware luxury consumer is looking to make more conscious and savvy purchasing decisions through "voting with their wallet" (https://www.appearhere.nyc, 2017). As mainstream brands strive to tap into the trends of leveraging sustainability to sell product, consumers will become better at judging authentic provenance from 'greenwashing ${ }^{3}$ (Earthtalk, 2013). Modern luxury brands are uniquely positioned to lead the way in provenance and responsibility.

3 Greenwashing involves falsely conveying to consumers that a given product, service, company or institution factors environmental responsibility into its offerings and/or operations. http://business-ethics.com/2013/04/21/1838-what-is-greenwashing/ 
Early definitions of the concepts of social responsibility were developed in the business literature (Caroll, 1999). To determine what being socially responsible means within the fashion industry, Dickson and Eckman (2006) conducted a survey of academics asking them to define the term socially responsible apparel and textile business. From the participants' responses they derived the following conceptual definition.

"Socially responsible apparel and textile business involves:

- An orientation encompassing the environment, its people, the apparel/textile products made and consumed, and the systematic impact that production, marketing and consumption of these products and their component parts has on multiple stakeholders and the environment

- A philosophy that balances ethics/morality with profitability which is achieved through accountability-based business decisions and strategies.

- A desire for outcomes that positively affect or do very little harm to the world and its people" (p.188).

Social responsibility and sustainability are concepts that surely will affect consumers and future fashion businesspersons. An ever-increasing number of consumers are demanding that businesses pursue more than just their financial situation using the triple bottom line system of accounting which suggests that "a corporation's ultimate success or health can and should be measured not just by traditional bottom line, but also by its social/ethical and environmental performance" (Norman W. and MacDonald C., 2004, s. 243).

Recent magazine and newspaper articles, books, documentaries, blogs, conferences, movies, urban legends, word of mouth and social media have raised consumers' awareness of social and environmental issues related to the production and consumption cycle. The number of consumers who tend to purchase apparel from companies that attempt to limit harm to the environment and people have increased. In their study Shaw and Tomolillo (2004) found that consumers were anxious about a number of issues including the use of chemicals in the production of textiles, the use of animal fur and the general ethos and conduct of fashion industry. Participants also had negative opinions of the fashion industry since they thought that it was aggressive, arrogant and superficial (s.146).

Correspondingly luxury brands have eventually been integrating green concepts of sustainability and responsibility at the core of their design process. Both luxury conglomerates and more micro designers are increasingly taking into account their environmental impact and pursue more sustainable and responsible products with provenance. New York-based Maria Cornejo, for instance, put up a collection for SS17 under her Zero + Maria Cornejo label defined by architectural drapes and contemporary lines as well as its use of a unique white fabric manufactured from wood pulp and sourced from sustainable forests in Domsjo, Sweden (http://www.zeromariacornejo.com/ edi-pants-32862, 2017). Longtime sustainability advocate Cornejo names this fashion production approach as Eco Drape which she explains as "an ongoing challenge to produce as designer collection in sustainable ways. We use fabric that's responsibly sourced from forests in Sweden from trees that are reforested so then they avoid deforestation. We use a recycled cashmere as well-all the ends that would usually get thrown away when the yarn has been spent gets spun into new yarn with new life and another fiber to make it. We also use vegetable dyed leathers on some of our shoes. We're trying to do whatever we can. The goal is every season, to make one more aspect or section of the 
collection sustainable. Seventy percent of the collection is made in New York except for the knitwear, which is made in Bolivia with local yarns and uses organic bio-tape and a plastic recycled tape. We work with a vertical women's factory there and in Peru. All of these indigenous women are knitting there with their children, to help support them. They make the yarn and also do the knitting, so it's about keeping things local whenever possible. We are also working with a company in Italy that prints with less water. And there's air printing, which just means the dyes get sprayed on with less water" (O’Neill, C., 2017).

This wave of fashion designers holds that people are not buying blindly anymore, and pursue transparency. There is a considerable number of savvy consumers who want to be informed about where their clothes were made. Although Cornejo's brand is independent and niche, changes in textile production are also taking place across the broader luxury consumption-scape driven by the Paris giants. LVMH, for instance, has an actively functioning, 'environmental department', while Kering recently published guidelines titled "Crafting Tomorrow's Luxury" specifying what it aims to achieve in terms of sustainable development. The umbrella corporation, which owns Gucci and Stella McCartney, aims to confirm the origins of all its raw materials, including their country of extraction, by 2025, "to ensure a transparent and responsible supply chain". Kering has also pledged to cut its greenhouse gas emissions by half over the same period of time (http://www.kering.com/en/ sustainability/news/crafting_tomorrows_luxury).

Japan where production techniques are notably experimental is also a considerable spot for environmental consciousness. The Issey Miyake label, 1325 launched in 2010, produces some of the most augmented apparel on the planet, all derived from material using recycled PET thread. Miyake's technique produces approximately 80 per cent less $\mathrm{CO} 2$ than the process of creating polyester from petroleum. "Issey Miyake has always been interested in keeping the balance between excellent craftsmanship and technological innovation. Yet, for our concepts, the need of human hand is indispensable" points out Miyake

(http://pluckedchickenbysandrapfeifer.blogspot.com.tr/2009/03/dai-fujiwara-talks-about-his-workand.html, 2009). Conversely, another prominent Tokyo designer Yohji Yamamoto holds with natural fabrics for his collections claiming his dislike of synthetics: "I don't like using fabric produced using oil. We are creating a disaster on the earth. I like cotton and wool. I see fabric as a second skin, and it needs to let you breathe" (https://www.ft.com/content/cabf4d6a-0359-11e7-aa5b-6bb07f5c8e12, 2017).

Obviously it is a challenge to produce a designer luxury item in a sustainable way. Sustainable and ethical fashion should not be considered as something out of the luxury concept but rather as a given since it is the direction the industry is heading. Many designers similarly believe that sustainability and humanistic considerations pose a concern for the consumer of today. While caring about sustainability and acting responsibly people still want beautiful things that have the right message and geniality behind them.

\section{Re (F) Use Renaissance Story: Refusing The End Of It All By Reusing Gracefully What's At Hand}

"As a designer, I feel responsible for the life cycles of the objects I create. Facing the social and environmental problems of today's world, I think the general idea of beauty involved in the concept of design should be enriched by the values of truth and good." Ilaria Venturini Fendi. I mainly wanted 
to exemplify this shift through an accessible luxury brand I met and fell in love with while on a business trip I made to Rome to study established Italian luxury brands such as Fendi, Gucci, Bulgari and Prada. The new Renaissance in luxury branding idea dawned on me through a brand named RE(f)USE founded by one of the daughters of Anna Fendi, the long renowned Italian luxury brand artisan. The bottom line in the luxury industry is the ability to tell a story that makes customers feel unique emotions. Italian brands are rich of aura and emotional content. The main critical approach behind Italian design is that Italian artisans brand luxury experiences, from the idea to the product by analyzing the critical success factors of the Italian brands, such as "Small is smart; We are family and Business is an art".

Moreover, successful Italian brands possess a unique strong identity and corporate culture, deeply ingrained in the local culture. Understanding the relationship between Italian micro multinationals and the territory where they are born and flourish is of fundamental importance to grasp the distinctive features of the 'Made in Italy' brand. This combination radiates eventually as unique products and experiences through adding pleasure, ease and satisfaction to the fulfillment of basic needs. For the RE(f)USE brand, sustainability has become a key component in branding luxury toward clients' commitment, shareholders and stakeholders' involvement and perceived added value.

\section{Ilaria Venturini Fendi's Carmina Campus Creating Without Destroying: Ethical Fashion Born in Rome}

The youngest daughter of Anna Fendi, one the five sisters heading the historical Fendi fashion house, Ilaria Venturini Fendi began as Accessories Creative Director of Fendissime and Shoe Designer of the Fendi line. Few years after the family firm was acquired by a French group she left the luxury world to become an organic farmer. Taking a short leave of absence from the world of high-end fashion, she turned a large piece of land just outside of Rome into an organic farm, I Casali del Pino, driven by an approach of restoration according to bio-architecture and landscape safeguarding. Inspired by her work on the farm, she returned to her roots as a fashion designer. In 2006, Venturini Fendi crafted the Carmina Campus brand which brings together ethical sustainability and fashion through an exclusive touch of design, artisanship, luxury and consumer responsibility.

Ilaria Fendi welds her magical craft with the environmental values and voluntary simplicity she counts on and personally lives by. Her expertise as a designer intersects with the eloquently skilled craftsmanship of Italian artisans like that of her mother Anna Fendi in the crafting of bags, accessories and furniture with all kinds of reclaimed materials. Soon after Carmina Campus was established, she started working in Africa to produce semi-finished items that was to be utilized in a special 'Made in Italy' line. The project was supporting a community of disadvantaged women in Cameroon. Often invited as a speaker, such as at Rio+20 during the ITC session on Ethical Fashion and at Suzy Menkes' International Herald Tribune 2012 luxury conference, she has received various international awards for spotlighting Ethical Fashion and its place in the future. Besides, in 2011 she received the Fashion 4 Development Award from the hands of Franca Sozzani in Seoul and in 2012 the Excellence in Ethical Business Award by Dallas Mayor Mike Rawlings. In September 2015, she was a speaker at the "Global Maker Movement - The Culture \& the consumption Forum", organized by the Beijing Design Week. She is an active advocate of campaigns supporting social development and sustainable economy and is a member of 'The Circle', a non-profit organization created in the UK by Annie Lennox and Livia Firth to promote women' rights and empowerment. 
Within the framework of its mantra "save waste from waste", Carmina Campus sources industrial materials that are commonly considered as waste but inspire its collections. In the hands of highly skilled Italian artisans these artefacts acquire a brave new life as part of a design object.

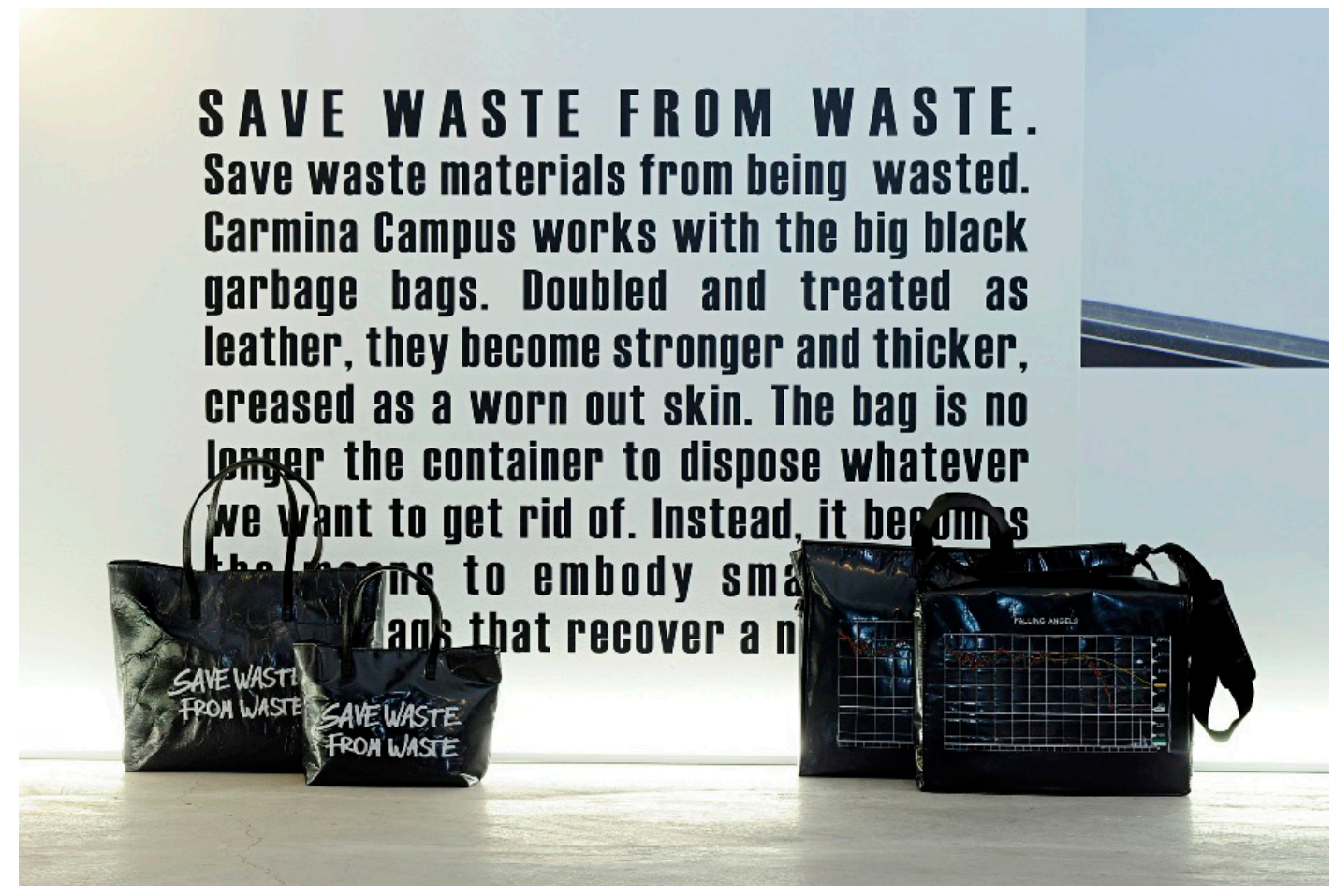

Figure: 2 Carmina Campus Brand Mantra

(http://www.carminacampus.com/concept/).

Materials collected for this purpose may be end-of-lines, vintage, unused or defective materials that do not comply with quality production standards and also scraps and off-cuts of whatever kind that are turned into state-of-the-art bags, jewels or furniture. Each bag is numbered and catalogued and the materials used are listed on a tag. As individually unique pieces, in which no two items are ever alike as to material and composition, all the items are definitely customized. Year after year, a huge number and variety of materials were given a new life. The list comprises soda can bottoms that inspired an entire line called Space Waste. Tin cans and pull tabs have been derived into bracelets, rings, earrings and necklaces. The leather and fur used for the bags always come from Italian manufacturers' color sample swatches or from remnants of the RTW or glove industry. Swatches are usually employed leaving their number or name codes visible.

Carmina Campus collections are not necessarily seasonal, but rather developed from a given repurposed material or a special feature. The same style may have several renders or expand from one collection to the other with brand new feels and looks supplied by different materials and assemblages. Interior design items are equally unique and appreciated as artistic works. Chairs, tables, lamps are all exclusive and exceptional pieces in which the original function of materials is reinterpreted to concoct something absolutely authentic and new. 


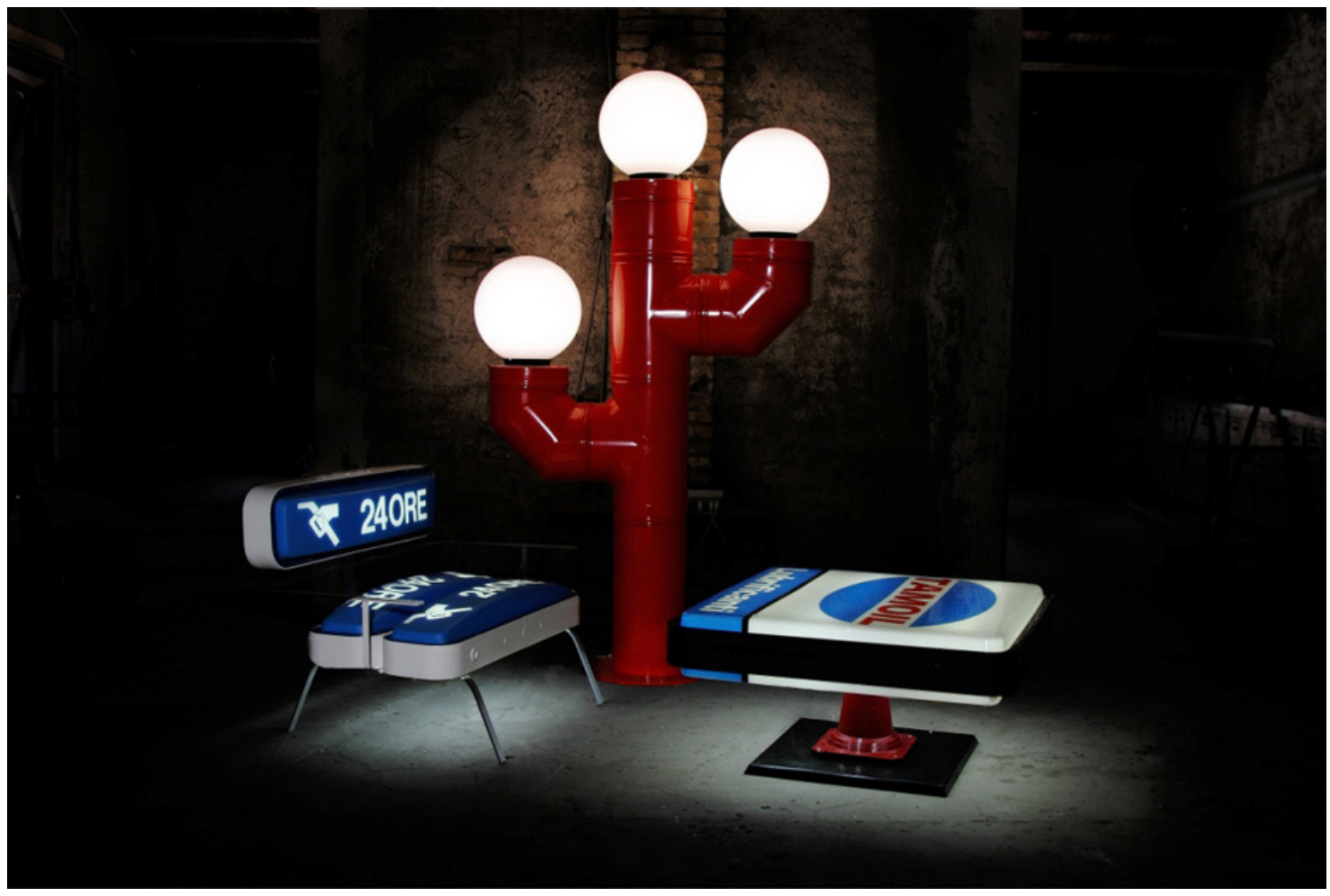

Figure: 3 Recycled Reinterpretations by Carmina Campus

(http://www.carminacampus.com/concept/).

Following a series of work in Africa with the UN agency International Trade Centre, Carmina Campus is now a partner of Socially Made in Italy, a group of social work institutions that operate within Italian prisons for rehabilitation working programs, executed under the supervision of the Italian Ministry of Justice. In collaboration with the UN International Trade Centre (ITC) agency, that fights poverty through the creation of employment opportunities in Africa, the brand has launched social projects that aim at assisting with female microentrepreneurs, and supporting education and health care.

Ilaria Venturini Fendi has adopted the ITC's philosophy, "NOT CHARITY JUST WORK", and pioneered the Ethical Fashion Initiative in which several crafts people and employees have been and passed on their know-how to local communities through a process of on-site training. Scraps of traditional fabrics such as 'shukas', the Masai drapes with tartan design, mixed with printed cottons like 'khangas' as well as other second-hand materials have been used to create the bags in this $100 \%$ Made in Africa line. 


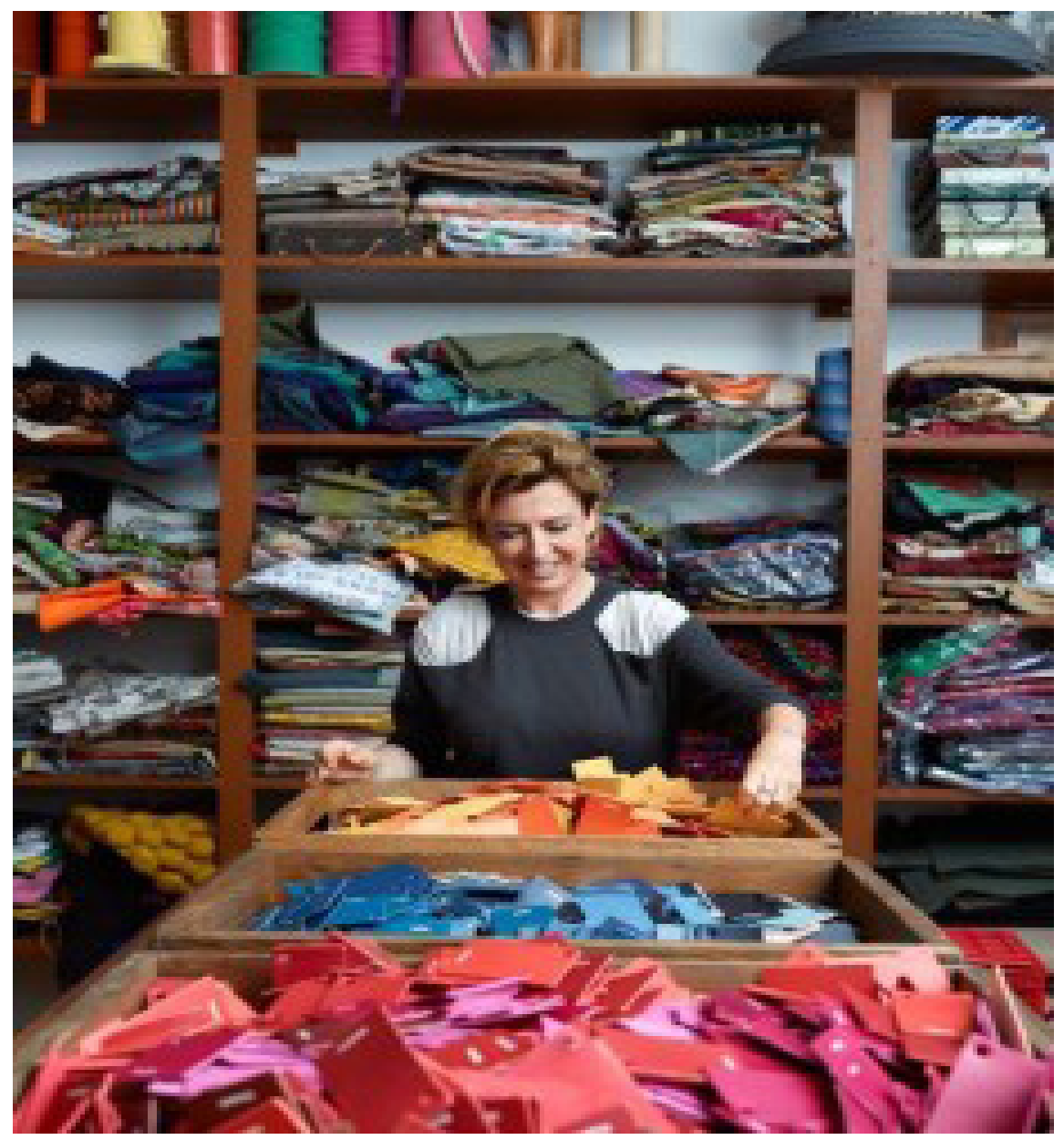

Figure: 4 Ilaria Venturini Fendi's Atelier at Carmina Campus

(http://www.capolavoroitaliano.com/precious-things/2036/carmina-campus-the-ethical-fashion-was-born-inrome-and-now-flies-to-africa/).

Wasting is not only terribly unfashionable for Ilaria Venturini Fendi, but also causing irreversible damage to our own health as well as that of the planet. What's more, her sensitivity and ability to bring the environmental message to a larger number of affluent people deserves scrutiny and respect as a case study and obviously this initiative led by her can easily be described as a revolution in consumer behavior realized through a consumer tool. Her audacious and humane luxury touch can even be felt through a more militant vibe when one hits her experimental boutique down in the heart of Rome.

\section{RE(f)USE : Reduce, Reuse and Recycle}

RE(f)USE is a luxury brand concept in accessories category based upon the three R's: Reduce, reuse and recycle. The three R's have been making their way into the fashion world with new force especially in the past years, and I would like to share and depict the story of this new off-Roman iconoclastic Italian brand as a strong and valid example that uses recycled materials to keep waste to a minimum while creating elegantly unique luxury products the consumers find extremely inspiring 
and relevant. I will try to pinpoint the evolution and redefinition of luxury idea from high-fashion looks to eco-conscious downshifting with upcycled handbags made from old car seats worth 200 Euros and so on.

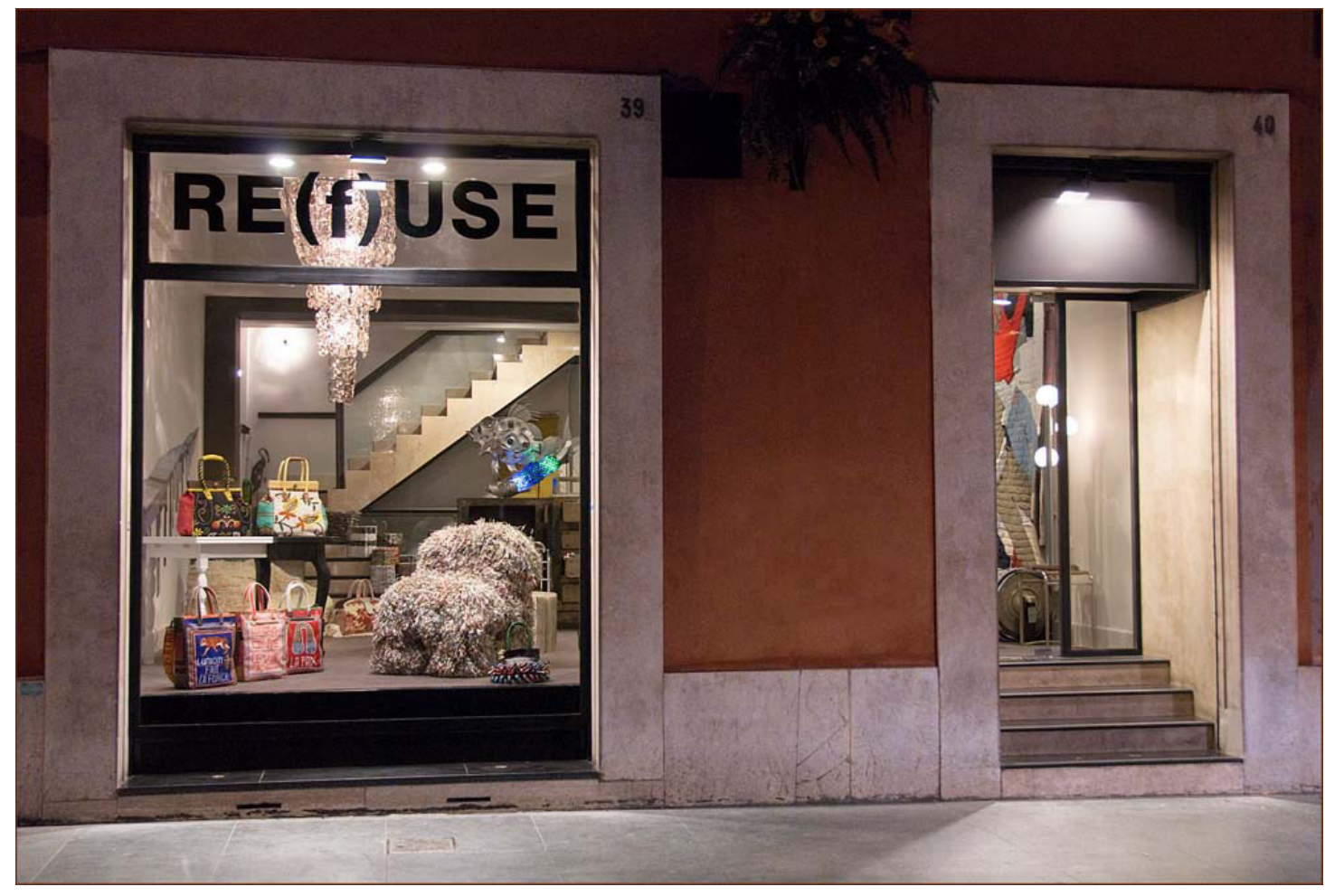

Figure: 5 The boutique: Rome, Via Fontanella Borghese 40

(http://www.carminacampus.com/refuse/).

RE(f)USE is the experimental store of Carmina Campus in Rome dedicated to the concept of 'upcycling' and 're-using' refused materials. Many pieces from Ilaria Venturini Fendi's various collections are displayed, along with works by other unconventional creative designers who recycle/ reuse waste materials.

Fascinating to browse, this smart and magical boutique exhibits unique Carmina Campus items primarily bags and jewelry made from upcycled objects and recycled fabrics where one feels herself as a heroine delving into the Wonderland of Alice. The brand is obviously the love child of Ilaria Venturini Fendi where you can feel her passion, advocacy and geniality vis-à-vis ethical fashion. Here you can bump into contemporary bracelets and earrings made from beer and soft drink cans, and bold bags from recycled materials. Upstairs, upcycled street signs become armchairs, computer keyboards become dining-room chairs, and the large petrol signs found at gas stations stand still as remarkable table tops. The ironic spirit of arts and crafts meet merge with the muses to conceive iconic pieces embracing consumers holding on to human touch, natural bricolage and resisting spirit. 


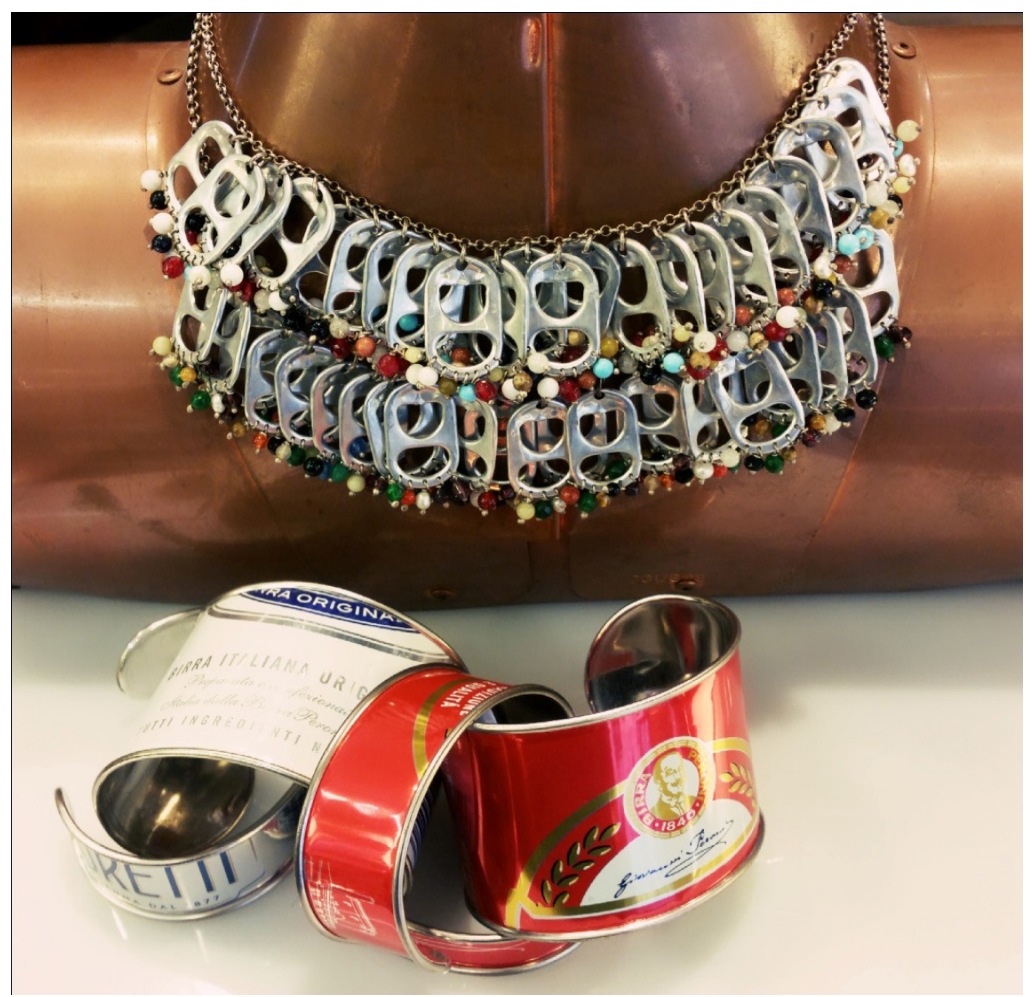

Figure: 6 Recycled necklaces and bracelets by RE(f)USE

(http://www.carminacampus.com/refuse/).

Owing to this brave group of downshifting designers like Ilaria Venturini Fendi we will not for long be talking about "eco" fashion as an alien concept to luxury marketing. Considering the social, political and ecological perils and turmoil the world is facing today, this industry will too have to revise its standards so that such a distinction would not be needed in a near future. Obviously today's chic and style could be different tomorrow. In the context of luxury design if we take into account and live by only precious materials such as fine leather, gold, gems and furs then a bag manufactured of reused stuff would by no means considered as a luxury item and does not conform to traditional style standards. However when we consider all the body of research mentioned above, high-quality, fair trade manufacturing, superior design approach and concept behind all these above shown items and their one-of-a-kind status, then indisputably one can still have a new, and a very personal style. Through the lenses of these iconoclastic designers, I realized we can look at things in a different light finally accepting the idea that more ethics does not necessarily mean less aesthetics.

\section{Conclusion}

Thus, in response to affluenza, we also see a new breed of luxury designers as well as consumers willing to participate in the voluntary simplicity movement as affluent but socially conscious individuals keep on expressing a variety of concerns about environment, overconsumption, abuse of developing nations and extensive advertising. The actual modification of consumer behavior can be a committing task, especially now that we are going through hard times of tough crisis. Habit can be the most resistant factor to change, and this can be true also about recycling, sustainability 
concerns, fair trade considerations and so forth. However, economic experts and those who analyze these phenomena and transformation agree that fashion consumers are gradually modifying their buying attitudes and behaviors. As a result I believe fashion will increase its offerings, and there will be more space for new approaches and trends.

The recession and digital revolution brought with them a new set of values and expectations. Luxury became less about buying and accumulating branded things, more about the stories and experiences surrounding the brand. Where once the industry thrived on prescribing people what they needed to have, today's brands are striving to understand and adapt to what their customer wants. A new generation of consumers is emerging. They have already influenced the rise of digital-first brands, the adoption of new technologies in the luxury space and challenged the traditional players in the industry. It is clear that the time to adapt or face becoming a relic of the past has come already. What constitutes "Luxury" thus is a malleable definition. It takes on new meanings across cohorts and cultures. When it comes to the industry however, there seems to be a global shift in a positive direction: less consumerist appeal, more authenticity, more transparency and a better overall experience.

A decade ago, the term 'luxury' might have brought to mind images of celebrities carrying the 'in bag' of the season, flashy logos, five-star hotels and snobby boutiques. Today, those rules of what we understand as 'luxury' have changed dramatically. Changes in the luxury branding and the consumer markets have also disintegrated certain conventional notions of luxury. The internet has changed the way luxury items are accessed and contributes to the changing consumer psychology and perception of luxury. Shoppers can even now also borrow luxury goods from several companies like bagborroworsteal.com and milaandeddie.com. These possibilities are creating new attitudes to luxury and more challenges to managing luxury brands. Innovation and good will aspects of luxury goods are also of great importance and integral to a luxury brand's sustainability and relevance. The brand is the reason that consumers associate themselves with a luxury company. It is what creates and sustains the attraction and desire for products. The strong attachment that luxury consumers have to brands, which often defies logic, is the result of branding. Brands are not generic products and should not be managed within a generic perspective. Brands are a complete package that provides a source of identity, a soul if you will, for products. This identity becomes a springboard for the strong and favorable associations and perceptions eventually developed in the minds of consumers. This is what draws the new consumers of today to luxury brands and remain their source of satisfaction and inspiration.

\section{References}

Caroll, A. (1999). Corporate Social Responsibility. Business and Society. 38(3). 268-295.

Chesterfield, W. (2017). The Post-Luxury Consumer.

www.luxurysociety.com/en/articles/2017/01/post-luxury-consumer/

Collins, M., \& Weiss, M. (2015).

https://www.researchgate.net/publication/283671049_The_role_of_provenance_in_luxury_textile_ brands Apparel

Dickson, M.A., \& Eckman, M. (2006).Social Responsibility: The Concept As Defined By

And Textile Scholars. Clothing and Textile Research Journal. 24(3).178-191. 
Gardyn, R. (2002). Oh, The Good Life. American Demographics. 34.

Lee, A., Linowes, R. (2009)

auislandora.wrlc.org/islandora/object/0809capstones\%3A197/datastream/PDF/view.

Norman, W., \& Macdonals, C. (2004). Getting To The Bottom Of "Triple Bottom Line." Business Ethics Quarterly. 14(2). 243-262.

O’Flaherty, M. (2017). The Eco Has Landed: Sustainability Gets Stylish. Financial Times. https://www.ft.com/content/cabf4d6a-0359-11e7-aa5b-66b07f5c8e12.

O’Neill, C. (2017). Designer Maria Cornejo Talks Fashion's Effect On The EnvironmentAnd How The Way You Shop Can Help.

www.marieclaire.com/fashion/news/d26402/maria-cornejo-on-sustainable-fashion.

Reese, S. (1997). The Many Faces Of Affluence. Marketing Tools. 44-48.

Richins, M.L. (1994). Special Possessions And The Expression Material Values. Journal of Consumer Research. 21.522-533.

Richins, M.L. (2013). When Wanting Is Better Than Having: Materialism, Transformation Expectations And Product-evoked Emotions In The Purchase of Products. Journal of Consumer Research. 40(1).1-18.

Rindfleisch, A. Burroughs, J.E., \& Wong, N. (2009). The Safety Of Objects: Materialism, Existential Insecurity And Brand Connection. Journal of Consumer Research. 36. 1-16.

Schultz Kleine, S., \& Menzel Baker, S. (2004). An Integrative Review Of Material Possession Attachment. Academy of Marketing Science Review. 1.

Solomon, M.R. (2017).Consuming Passions.

https://michelsolomon.wordpress.com/author/michaelsolomon/

The New Rules Of Modern Luxury, 2017.

https://www.appearhere.nyc/inspire/blog/the-new-rules-of-modern-luxury-af66e13f-1162-45e2a40e-0ff3e0fbba95.

What Is Greenwashing, (2013). Earthtalk. Business-ethics.com/2013/04/21/1838-what-isgreenwashing. 